\title{
The Experiences of Grandparenting in Indonesia
}

\author{
Azam Syukur Rahmatullah", ${ }^{1, *}$ Suyatno ${ }^{2}$ \\ ${ }^{1}$ Department of Educational Psychology, Universitas Muhammadiyah Yogyakarta, Indonesia \\ ${ }^{2}$ Department of Education Management, Universitas Ahmad Dahlan, Indonesia
}

Received July 2, 2020; Revised August 26, 2020; Accepted October 19, 2020

\section{Cite This Paper in the following Citation Styles}

(a): [1] Azam Syukur Rahmatullah, Suyatno, "The Experiences of Grandparenting in Indonesia," Universal Journal of Educational Research, Vol. 8, No. 11, pp. 5589 - 5598, 2020. DOI: 10.13189/ujer.2020.081163.

(b): Azam Syukur Rahmatullah, Suyatno (2020). The Experiences of Grandparenting in Indonesia. Universal Journal of Educational Research, 8(11), 5589 - 5598. DOI: 10.13189/ujer.2020.081163.

Copyright $@ 2020$ by authors, all rights reserved. Authors agree that this article remains permanently open access under the terms of the Creative Commons Attribution License 4.0 International License

\begin{abstract}
This research aims to explore the way grandmother's struggle hard in educating her grandchildren, who are entrusted to them by their biological parents. This research is a field research with a phenomenological approach. The research location was in the Puring, Kebumen, Central Java, with three grandmothers who are considered successful in raising and educating their biological grandchildren. The three grandmothers were taken into a sample based on appropriate criteria and were deemed to be successful in applying mental resilience education to their biological grandchildren. Grandchildren who are used as objects of research are also those who are considered successful in implementing mental resilience education imposed by their grandmothers. The findings of this study stated that from these three grandmothers in Puring Kebumen, all of them had concepts and actions that were appropriate and clear to be applied to their grandchildren. Some of the findings include the act of not spoiling grandchildren except in a natural way, obliging grandchildren to solve their problems without always being assisted by grandmothers, providing love and care for grandchildren appropriately, introducing grandchildren to the real struggle of life such as trading or selling, and also obliging grandchildren to live independently and fulfill their obligations.
\end{abstract}

Keywords Grandparenting, Mental Resilience, Education, Phenomenology

\section{Introduction}

Early childhood education is a prudent education because children enter the golden age phase in this stage, where the pattern of education and nurture can determine future destiny, and establish the nature and behavior of children in the future [1]. The pattern of education and nurture from figure attachment, which inherent unconditionally, will make the child grow mentally healthy and have a mature personality. It is different if the figure attachment does not provide adult education and nurturing; it will make the child have an immature mentality [2].

The education and nurture for early childhood should ideally be applied by both parents together rather than being partial, which is only mother or father. On the other hand, the best education and nurture for children are not handed over to grandmothers but directly raised by both parents. Although, in reality, there are still many children who are cared for not by their parents but by their grandmother, whom the writer calls the term "grandmothers as the mother" or other terms "grand-parenting."

According to the results of the study, it was found that primary education and nurture for children by grandmothers was risky for children. It said to be unsafe because they lost the origin of figure attachment, i.e., father and mother [3]. On the other hand, a grandmother who does not upgrade her parenting science will misstep in raising and educating children. In the end, the parenting can make children misdirected. For example, pampering care from the grandmothers will produce children who are spoiled in life, unable to face the reality of life, easily broken and discouraged, easy to complain, have weak mental [4].

Vice versa, the "authoritarian" education from grandmothers will bring the child to an atmosphere (stemming) that is easily shaken, loses self-image, needs 
caress love, anti-social, more solitary, and various other weaknesses [5]. Therefore, education and parenting of grandmother as mother ideally need to pay attention to the needs of the soul, the mentality of children, and the significant effects of post-care and education. If you do not pay attention to these things, it is feared will lead the child to a phase of mental degradation, and mental confusion.

However, in the reality of some instances, there is the practice of grandparenting, which can be categorized as successful. Some indications of their success in educating children mentality can be seen from several criteria, including; first, the child is agile and active in peer friends. Second, children do not cry easily, and even tend to be tough in various situations. Third, the child never complains, mainly complaining about the existence of his parents, who are separated from him. Fourth, it is not easy to collapse in any situation. Fifth, achievers in class and school. Sixth, the children actively carry out worship and pray five times independently. In general, children are still governed and reminded to have five-time pray a day. However, in this case, children whose successful educational and caring patterns "already have the self-awareness to worship." Seventh, polite in behaving. Eighth, gracious in speaking to older people, not rude in speaking.

This study examines three grand-parenting practices conducted by three grandmothers in Kebumen district, which can be an example because they have brought their grandchildren to be successful people. On average, the three grandmothers educate and care for their grandchildren since they are babies. The three grandmothers train and nurture their grandchildren with a holistic nature, namely education and care from physical, spiritual, cognitive aspects, with the assistance of contemporary parenting science. Based on that condition, the researchers sought to dig deeper into "the success of the grandmother in caring for her biological grandchildren," which led to good mental resilience.

\section{Literature Review}

\section{Grand Parenting and Children's Mental Resilience Education}

Grandparenting is a term in the world of Psychology as a form of nurture carried out by a grandfather or grandmothers to his grandchildren [6]. In this case, a grandparent becomes the "surrogate role" of biological parents in caring for, raising, and educating their grandchildren.

There are several reasons why a grandmother can be used as a "surrogate role of caregiving" and to be a "figure attachment" as a substitute for parents over their grandchildren [7] some of which are: First, the death factor of the child's father and mother, which then the custody rights inevitably was taken by the grandparents. Second, the divorce of parents (the father and mother of the child), which results in the separation family then, the parent cannot properly care for the children, which is ultimately taken over by the grandparents. Third, both parents worked in the city, and abroad makes the child is entrusted to the grandparents of the children. Fourth, parents run away from the responsibility of caring for children; they both leave the children, which in the end, his grandparents must care for and raise their grandchildren.

Grandparents care for grandchildren is not necessarily "double touch," which is two touches from grandparents. Many grandchildren are taken care of just one touch, namely by his grandmother only because the grandfather has died, or by his grandfather only because the grandmother has died. It is a fortune for a grandchild if he receives perfect and complete grandparenting, namely the care of his grandparents until adulthood.

Although in reality, "not a few" grandchildren who did not get a double touch until adulthood, because one of the grandparents passed away. Thus, on the way to the process of growth, development, and maturity, grandchildren are only cared for by grandmothers only, or grandparents only. There are several reasons why grandparents are willing to be a "substitute role" in caring for their grandchildren: First, feeling sorry for their grandchildren. The idea of "sorry" is the main factor of a grandparent willing to take care of his grandchildren. They do not want their grandchildren to suffer from the loss of their parents' figures and affection; then, the only way that grandparents can take is to care for them and educate them wholeheartedly, like biological parents caring for their children. Second, substituting the responsibility, it means the reason grandparents are willing to care for their grandchildren is because it is a blood responsibility. Thus, it inevitably has to become a substitute figure of biological parents for the grandchildren. Third, maintaining the morality and ethics of grandchildren, that is, grandparents do not wish their grandchildren to lose morals and ethics in life because there is no one to guide and direct them in the course of their lives. Thus, grandparents are willing to replace the role of parents into "moral figures" for their grandchildren, in the hope that their behavior and morality will be maintained and safe even if they do not have perfect parental love. Fourth, Educate grandchildren's mentality to have resilience because grandparents realize that children who lose their parent figure will be more at risk of contracting a mental illness, and mental confusion. Thus, grandparents are willing to become "mental figures" for their grandchildren; then, their mentality can develop well and be healthy.

\section{Grandparenting Style}

There are several types of grandparenting methods towards their grandchildren: First, authoritarian parenting style, i.e. strict the nurture for grandchildren. This style is 
carried out because the level of concern of grandparents to their grandchildren is high. Therefore, the grandparents seem to force their grandchildren to follow all the rules. It under the pretext of "this is all for the good of grandchildren.” Generally, grandparents pay little attention to the adverse effects of their authoritarian attitude on their grandchildren. The most important thing for them is "their grandchildren must follow all the rules if they want a better life."

Second, permissive parenting style, a parenting style that "spoil the grandchildren." In this case, "an affection of grandparents" to their grandchild is reflected by obeying the requests of the grandchildren. It is conducted by the intention of making their grandchildren happy. This practice is on the pretext that the grandchildren have lost the figure of parents and live in misery; then, whatever the wishes of grandchildren, the grandparents will seek to make them realize. In the end, this action will make a grandchild as a spoiled child, and cannot stand alone because his life is full of dependence on his grandparents. This kind of parenting style will only plunge a grandchild into permissive behavior.

Third, the authoritative parenting style, in which this parenting style prioritizes logic and positive thinking and does not always use punishment as the ultimate resource. Grandparents and grandchildren establish excellent communication; on the other hand, grandparents provide balanced and healthy control and support to their grandchildren so that their grandchildren's personalities thrive as well [8].

The style of grandparenting who can bring good mental resilience to their grandchildren is a style of parenting that is not too tightly binding, does not disappoint the grandchildren, and brings the grandchildren's mentality to enlightenment and significant meaning in his life. Ideally, achieving a high mental resilience in grandchildren is a goal that becomes the main concern by grandparents. This achievement also aims to ensure that his grandchildren can survive, be independent, not be easily swayed and broken, and not easily depend on the attachment figure. Therefore, a grandparent must educate their grandchildren's mental resilience well and be consistent with a constructive style of care rather than destructive.

Mental resilience education is an effort to improve the "mental quality of children" so that children can face difficulties, able to find solutions to problems that occur, are not easily upset and discouraged. Utami et al. [9] stated that mental resilience education is an effort to direct children to positive adaptation patterns during or after facing difficulties or risks. Rojas [10] said that mental resilience education is a medium of "self-change" to children from a state filled with pressure towards a direction full of opportunities for personal self-development so that it becomes better.

Some signs of children who have excellent or healthy mental resilience, according to Dewi and Henu [11], include; (1) individuals have a strong personality and are not easily paralyzed. (2) Individuals have positive emotions. (3) Individuals have reasonable self-control. (4) Individuals can rise from failures and adversity. (5) Individuals have superior interpersonal and intrapersonal intelligence.

Asriandari [12] said that signs of mental resilience of healthy children and adolescents include; (1) keep calm in facing any problems and pressures. (2) Have good self-regulation. (3) Able to manage emotions well. (4) Optimism in life and life.

In this case, children need to get an introduction and education of mental resilience from an early age, with the hope that children can live their life processes healthily, and not become weak individuals. Instead, the child will become a healthy person and ready to face whatever happens. This mental resilience education should indeed be taught to children from an early age, even from the womb. When the prospective baby is in the womb, the potential baby has received a transfer of mental motivation through conversation with mothers and fathers. In essence, the prospective baby can already hear, feel, and understand what is conveyed by both parents. Thus, early childhood mental resilience education is a necessity for both parents of prospective babies.

When the baby is born, the responsibility of parents to develop and educate the child's mental resilience is increasingly higher. This consequence is caused by the child "will never know and understand" what will be experienced in the present and future. Thus, giving children an early mental education, in essence, is preparing their future and preparing for their success, which must be passed by "tortuous" [13].

\section{Research Methods}

\section{Research Design}

This research is field research in which researchers directly examine the research subjects in the hope that researchers find new things sourced from the research subjects [14]. The approach of this research is a phenomenological approach that seeks to uncover the meaning of an individual's experience [15]. Phenomenology essentially explains the phenomenon and its implications for individuals by conducting in-depth interviews with many individuals. In other words, this phenomenology is the study of excavation and definition of events experienced or lived by individuals with all their awareness. Then, it can be used as an alternative for others [16].

Samples were obtained using a purposive sampling technique. The research sample consisted of three grandmothers who successfully raised their biological grandchildren from infants to adults. An intentional sampling of only three subjects because no exact amount 
was specified in qualitative research [17]. The location of sampling for this study was in the Puring area of Kebumen, Central Java, Indonesia. This location is taken because, in this area, many fathers and mothers entrust their children to their grandparents. The parents left their children because of the large number of fathers and mothers who migrated outside their home regions and even abroad, such as Taiwan, Hong Kong, Malaysia, and Singapore.

The identities of the three grandmothers who raised their biological grandchildren and were considered successful in providing their grandchildren's mental resilience education can be described in table 1 .

Table 1. The Identity of a Successful Grandmother Caring for Her Grandchildren in Mental Resilience Education

\begin{tabular}{|c|c|c|c|}
\hline $\begin{array}{l}\text { Initial } \\
\text { Name }\end{array}$ & Age & $\begin{array}{l}\text { Initial Name of a grandchild who is cared } \\
\text { for }\end{array}$ & Information \\
\hline Mrs. Mar & 60 years old & $\begin{array}{l}\text { - AS (Cared for since the age of } 2 \text { years) } \\
\text { - AS's mother migrated to Jakarta to become } \\
\text { a cleaning service in a Company. } \\
\text { - AS's father has passed away since Ardian } \\
\text { was two years old. } \\
\text { - AS is } 15 \text { years old now. } \\
\text { - AS grew up to be an independent child, not } \\
\text { easy to complain, not easy to cry and } \\
\text { diligent in worship }\end{array}$ & $\begin{array}{l}\text { - Mrs. Mar nurtures and educates grandchildren } \\
\text { together with her husband. Caring is done with } \\
\text { income from her husband's retirees. Also, there was } \\
\text { additional money from Ardian's mother, although } \\
\text { not much. }\end{array}$ \\
\hline Mrs. AE & 65 years old & $\begin{array}{l}\text { - JS (Cared for since the age of } 1 \text { year) } \\
\text { - JS's mother and father are divorced. JS was } \\
\text { entrusted to his grandmother, Mrs. AE } \\
\text { - The mother of JS works in Taiwan as a } \\
\text { household assistant since Jaka was one year } \\
\text { old until now. } \\
\text { - JS grew up to be a brave child in school. } \\
\text { Jaka became an idol for his friends; he did } \\
\text { not easily lament his fate. JS was also polite } \\
\text { in his attitude and was well-liked by his } \\
\text { teacher and friends }\end{array}$ & $\begin{array}{l}\text { - Mrs. AE raised Jaka Satria by trading in the market, } \\
\text { although Jaka Satria's mother also sent money for } \\
\text { the living and school of JS. } \\
\text { - Mrs. AE's husband has passed away }\end{array}$ \\
\hline Mrs. SZ & 63 years old & $\begin{array}{l}\text { - MI (cared for since the age of } 4 \text { years) } \\
\text { - MI's mother and father are divorced, MI's } \\
\text { father has remarried, while his mother } \\
\text { works in Surabaya. Therefore, MI was } \\
\text { entrusted to his grandmother since the age } \\
\text { of } 4 \text { years. } \\
\text { - The Brotherhood grows into a child who is } \\
\text { not timid. He always told the truth, never } \\
\text { complained of a lack of affection. He also } \\
\text { does not easily cry lament the fate, keep } \\
\text { working, and become an achiever in school. }\end{array}$ & $\begin{array}{l}\text { - Mrs. SZ raised her grandchild alone at home } \\
\text { because her husband had remarried long ago. Thus, } \\
\text { economic life is supported by Mrs. SZ by selling at } \\
\text { food stalls. Besides that, Ikhwan's mother also sent } \\
\text { monthly money to help the finances of Mrs. SZ and } \\
\text { MI. }\end{array}$ \\
\hline
\end{tabular}


There are several ways of data collection techniques used in this study, namely:

\section{Direct Observation}

In this case, researchers conducted direct observations in the Puring Kebumen area, Central Java, Indonesia. This area has many children who are entrusted and cared for by their grandmothers. The average grandmother who takes care of her grandchildren has a job even though it is not "a civil servant." Most of the "grandmothers caring for grandchildren" work as entrepreneurs, opening grocery stores, food stalls, farming, and some are working odd jobs. Of the three respondents the researchers met, the three of them worked as food stall sellers, traded in the market, and some were just relying on retired salaries from their husbands.

\section{In-depth Interview}

Researchers conducted intense and in-depth interviews with three grandmothers who took care of their biological grandchildren since childhood. The interesting thing to be interviewed is because these grandmothers have telling tips to make their grandchildren have good mental resilience. These critical tips can later be used as role models for other grandmothers to educate grandchildren correctly and adequately. The two points presented in this phenomenological interview are; Textural Description. The first is the question relating to what is experienced by research subjects about a phenomenon. The second is Structural Description, namely how the subject experiences and makes sense of his expertise [18].

The data that has been obtained by the researcher is then analyzed with a phenomenological and editive reductive approach. There are several steps undertaken to investigate this data, i.e., (a) the initial stage, researchers describe adequately what is experienced by the research subjects. All results from in-depth interviews are translated in written form. (b) Horizonalization stage, this stage is the stage of inventory of essential statements following the topics discussed. (c) The stage of the cluster of meaning is statements of the subject that are then made clusters that indicate the condition of the subject. (d) In the essence description stage, the researcher constructs a thorough understanding of the meaning and essence of the experience of the subjects. (e) Researchers then report the results of research that have been studied. The report shows the experiences experienced by the subjects related to the way of educating the grandchildren to have good mental resilience [19].

\section{Results}

\section{Grandchildren Mental Resilience Education}

As explained earlier, the Puring, Kebumen, is an area that has many children who are entrusted to their grandparents. They live "depending on the care of the grandfather alone, or just the grandmother or both who are still alive." According to observations conducted by researchers, it is known that the children are left by their biological parents and are entrusted to their grandparents ranging in age from 1 to 5 years until they are teenagers. (Observations were made on January 1, 2020).

Child care for grandparents is carried out by biological parents because they work outside of their hometown. Some parents work in the country (indoor area). Some work abroad to become Indonesian Migrant Workers (TKI) in several countries such as Hong Kong, Taiwan, Singapore. (Interview with the village apparatus of Mr. St, January 1, 2020).

Some of the main reasons many mothers and fathers work as laborers elsewhere are: First, there is an assumption that life is making money in hometown is difficult. Moreover, income in the hometown is not substantial; then, it cannot meet daily needs. Second, there is an assumption that looking for work in a big city or abroad will get multiple benefits. This assumption can also be seen from the predecessors of Indonesian Migrant Workers (TKI) who are considered successful working in big cities and abroad. Third, parents want to meet the needs of their children. The parents hope that by working in big cities or elsewhere, they can send their children to school until college. Finally, children can get decent work and be better than their parents. The hope is that children who can have an established educational standard, their fortune will also be built. Later, these children will be able to raise the level of their parents and support their parents (Observation on January 1, 2020).

The economic urgency of parents (whether only mothers or fathers or both) makes them forced to leave their children with their grandparents. Also, transferring care that is ideally carried out by both parents to his grandparents. The care that is replaced by "the role of caregiver substitute" is also naturally "unlimited" and "cannot be determined by time." This quality reflects that parents who entrust their children are unable and cannot determine when they will stop being domestic workers and Indonesian Migrant Workers (TKI). Many of them are unable to give certainty the time to stop working when asked about time. As conveyed by Ms. My, one of the domestic workers who was successfully interviewed by researchers. Ms. My stated:

"I do not know how long I will be a domestic worker. I still need money to raise my child, who now lives with his grandmother. I cannot bear the economic problems imposed on my mother. My mother has revived the problem of parenting; it is inappropriate if financial problems also become my mother's responsibility. Therefore, once again, I don't know how long I will become a workforce like this, let time be the answer." (Interview with Mrs. My, daughter of mother Mrs. Mar, grandmother of AS, January 2, 2020)" 
One of the big problems for domestic workers and Indonesian Migrant Workers (TKI) is their ignorance of how long they will migrate. This uncertainty that ultimately makes the care of children by grandparent's increasingly long and having uncertain time. Such matters sometimes unsettle the hearts of these substitute caregiver roles. The reason is that caring for grandchildren is not as easy as caring for their biological children. It is difficult because the grandchildren are children of their biological children, which are not the absolute rights of the grandparents.

Moreover, if, in the end, the children are raised by their grandparents, their status remains "entrusted from their biological children," which means extra care and extra care must be taken in caring for them. Incorrect caregiving results in the complaint from native parents to a grandparent as a substitute role in the care of grandchildren. (Interview with Ms. AE, January 3, 2020)

This concern makes three grandmothers from the village of Puring, Kebumen, who "struggle with the truth" to care, nurture, raise and educate their grandchildren who are entrusted to them. The three grandmas are Mrs. Mar, Mrs. AE, and Mrs. SZ, who all came from the village of Puring Kebumen.

The three grandmothers above for years raised their grandchildren "who were surrendered" to them. As the results of researchers' search of his grandchildren, the three grandchildren raised by the three grandmothers have a good personality and mentality and are classified as healthy. This fact can be seen from their tough characters, not easily broken, not comfortable to cry if they have problems, rarely complain about the life they experience. They are also able to overcome difficulties, be achievers, always cheerful, and easy to get along with anyone.

According to JS, the grandson of Mrs. AE, who is now 15 years old, his grandmother always taught him many things, especially the meaning of resilience of life. She remained grateful to God for any gift given. This teaching made him able to survive, even without parents beside him (Interview with JS, January 5, 2020). AS, as the grandson of Mrs. Mar, who is now 16 years old, also justified JS's statement. AS said that his grandmother always accompanied him and taught him to be a person who is resilient, not easily uprooted, having good faith in God. The teachings conveyed by his grandmother were then lived and studied and then applied in his daily life (Interview with AS, January 7, 2020).

MI, the grandson of Mrs. SZ, also said something similar to AS or JS. MI told that the teachings of his grandmother to live independently, try to live life without complaining, keep smiling whatever happened, struggle to find a solution to the problems are lessons that the MI remembers and applies in his daily life (Interview with AS, January 7, 2020).

\section{The Style of Mental Resilience Education of Three Grandmothers}

As explained above, the role of the grandmother (grandparenting) in the care and education of her grandchildren "cannot be underestimated." They became "mujahids" for their grandchildren. They carry out the responsibility that is not easy because, in addition to the "moral responsibility," there is also a close relationship between grandmothers and grandchildren. Thus, the grandmothers become worried and uneasy if they do not educate and care for their grandchildren. The closest people who are related by blood are the grandmothers (Interview with Mrs. AE, January 3, 2020).

Based on the presentation of grandmothers and the crosscheck made by the writer toward grandchildren, it was found that grandmothers had provided maximum service to their grandchildren. This finding is consistent with the statements of the grandchildren taken care of by grandmothers with a super and extraordinary education and care. As stated by AS, grandson of Mrs. Mar, who said that:

"His grandmother is an extraordinary hero. He saw the struggle of his grandmother to raise, nurture, and educate him. Another impressive thing is her enthusiasm to continue to equip him with mental education that has increasingly benefited him" (Interview with AS, January 7, 2020).

The same thing was expressed by JS, who said:

"For him, grandma is not just a grandmother, but more than that. Her grandmother was the crown that God gave her to look after, care for, raise, and provide an exceptional education. Her stubbornness and continuity in raising him became an inspiration for JS to provide the best things for his grandmother. The most memorable thing for JS was the style of educating his grandmother regarding mental training, which for JS, was very useful. ” (Interview with JS, January 5, 2020).

Of the three grandmothers as informants, it was found that they have a style of nurturing and educating their grandchildren, especially related to "mental education." They applied a method of mental resilience education since their biological parents entrusted their grandchildren. The grandmothers are determined to direct the grandchildren to strengthen self-mentally. Self-mentality becomes the necessary foundation, and its nature is sustainable to be taught to her grandchildren. Thus, self-mentality is essential.

Based on observations in the field, the three grandmothers have the same style in mentally educating their grandchildren, namely, an authoritative manner. Authoritative style is "enlightenment" to children utilizing "emotional approach" and "opening mindset grandchildren." On the other hand, grandmothers try to provide insights that are animate and understand the grandchildren.

Regarding punishment, grandmothers still apply discipline to their grandchildren if they make mistakes even though the sanctions are not threatening and not 
traumatizing. The penalties applied are constructive penalties. The sentence is used, then after that, the grandmothers will give direction and enlightenment related to the reason they were sentenced.

On the other hand, grandmothers are also active in providing insights to grandchildren about why they must be strong in facing life, why they should not be whiny and weak, and why they must be tough in life. Grandmothers communicate by "incorporating values of strengthening mental resilience" while eating together. There is also a time after praying in congregation, they have the discussion, and it becomes an opportunity for grandmothers to give input and advice to grandchildren to strengthen themselves in life.

There is also two-way communication when cooking together; this opportunity is used by grandmothers to give a lot of knowledge about self-mentality. As stated by Mrs. $\mathrm{AE}$, who said that:

"I often discuss life with my grandchildren, especially when cooking together. This opportunity is a happy moment for me, with a relaxed style, we discussed anything while cutting the vegetables. We discuss how to deal with life. I feel that my grandchild is a friend and also my best friend. So, we can freely chat together" (Interview with Mrs. AE, January 3, 2020).

From the grandmother's and grandchildren's explanation above, it appears that the grandmothers did not apply an authoritarian and permissive style to their grandchildren. The three grandmothers agreed to stay away from the iron fist style of education because they realized that their grandchildren were the greatest gift in life that had to be best-taken care. They leave the culture of "just because," a mindset of "just because grandchildren are under the care of grandmother then, they can act arbitrarily, including saying harsh, iron fist, arrogant, anger without knowledge." Such things are avoided by grandmothers because they realize that these actions will only cause harm to grandchildren in the present and future. On the other hand, such behavior will only make the grandchildren as inferior, sensitive, anti-social, powerless in the face of problems. Therefore, grandmothers "do not adopt an authoritarian and a nurturing style of authority.”

Grandmothers also did not apply grandchildren's mental resilience education with permissive styles, i.e., styles that over-indulged grandchildren. Grandmothers avoid this style because it will only trap grandchildren with weakness and helplessness. According to Mrs. SZ, the grandmother of MI, it was stated that pampering grandchildren were legitimate because they also needed an affection "moreover, they did not have parents who could pamper at them any time. Still, this indulgence has rules, and its nature must be realistic. If grandchildren make mistakes and deviations, they have to be reprimanded and warned, not just left with the excuse "pity, or love grandchildren or do not want to make grandchildren angry," and so on. They must be educated professionals to get maximum results." (Interview with Ms. SZ, January 5, 2020).

From the statement of Ms. SZ, it is seen that pampering grandchildren are not a mistake as long as it is still within normal limits. However, it will be a mistake when the spending is excessive and does not make sense. Some of the inappropriate indulgent behavior towards grandchildren: (a) Remain silent even if grandchildren say harsh words, there is no attempt to remind them because of loving grandchildren. (b) Leaving his grandson smoking, rarely going to school, and still giving daily money on the grounds of not wanting to make his granddaughter sad and disappointed. (c) Never reminded his grandchildren to worship, even though his grandmother knew that the grandchildren left the daily worship, the reason was worried that the grandchild would be angry if reminded and did not want to go home again.

The various permissive styles above are "avoided" by grandmothers. They agreed that grandchildren should be pampered but with health spending, not error spending. Healthy spending is giving "spoiled" at the right time and atmosphere, without having to leave the rules that must be enforced to grandchildren. Meanwhile, error spending is a form of spending grandchildren without seeing right or wrong, violating or not, deviating or not. In this case, grandchildren will always be justified and never be blamed if they are wrong, distorted, and violated because of compassion, love, and humanity.

\section{Discussion}

This research aims to explore a grandmother's experience who has been striving very hard to mentally educate their grandchildren who are looked after and are babysat to them by the biological parents in grandmother's childcare. Based on the data analysis, the researcher found that the methods taken by grandmothers in caring for the grandchildren are by the act of not spoiling their grandchildren except genuinely conducted, obliging their grandchildren to solve their problems, without helping from grandmothers, not loving their grandchildren mistakenly, acquainting about the real life's struggle to grandchildren started from an early age, teaching their grandchildren to study about trade, obliging their grandchildren to live independently and finish their obligation. In detail, some forms of mental resilience education of three grandmothers applied to biological grandchildren are illustrated in table 2. 
Table 2. The Form of Mental Resilience Education of Three Grandmothers Applied to Grandchildren

\begin{tabular}{|c|c|}
\hline $\begin{array}{c}\text { The initial } \\
\text { Name }\end{array}$ & The Forms of Grandmother's Mental Resilience to the Biological Grandchildren \\
\hline Mrs. Mar & $\begin{array}{l}\text { - AS was always allowed to solve his problems. Mrs. Mar decided not ever to help solve the AS problem. } \\
\text { - Mrs. Mar gave AS homework assignments, such as; sweeping the house, watering flowers, cleaning the } \\
\text { - Aard. In other words, Ardian was trained to fulfill his house responsibilities. } \\
\text { individual needs; he is also independent. This action has been done since AS was childhood. } \\
\text { - When he was a child, AS cried because of difficulties. When AS cried, his grandmother only let her cry, } \\
\text { not immediately helping and giving love. This omission can be interpreted that grandma wants to see AS's } \\
\text { efforts in solving the problems he faces. }\end{array}$ \\
\hline Mrs. AE & $\begin{array}{l}\text { - JS has been invited to trade since childhood by Mrs. AE, although only accompanied. Mrs. AE } \\
\text { deliberately brought Jaka to be trained to live a simple life, struggle, and be patient in facing life. } \\
\text { - When he grew up, JS was able to trade independently with his grandmother in the market, and when his } \\
\text { grandmother was unable to trade, JS will replace his grandmother. } \\
\text { - Mrs. AE did not always intervene in the problems faced by Jaka unless Jaka asks for help or asks for a } \\
\text { solution from Mrs. AE. } \\
\text { - Mrs. AE always directs Jaka to live independently. This education can be proven by the obligation to } \\
\text { prepare JS needs without always having to be assisted by grandmothers. }\end{array}$ \\
\hline Mrs. SZ & $\begin{array}{l}\text { - Mrs. SZ always brought the MI from childhood to her food stall. Apart from the fact that no one } \\
\text { accompanied MI at home, it would also introduce the meaning of a struggle for life, stubbornness, and not } \\
\text { being a weak human being. } \\
\text { - Every time he comes home from school, the MI always helps his grandmother in the food stall. MI rarely } \\
\text { plays with his friends; he prefers to help his grandmother in a food stall while accompanying her. In this } \\
\text { case, Mrs. SZ felt that she had succeeded in educating MI to be a child with a steel mentality because she } \\
\text { rarely cried and complained. } \\
\text { - MI is always educated by his grandmother to complete homework, school, and food stalls, MI is taught by } \\
\text { his grandmother to balance them. }\end{array}$ \\
\hline
\end{tabular}

Based on table 2, it is seen how the three grandmothers applied mental resilience education to their grandchildren. The applied knowledge is education that is constructive rather than destructive. Constructive education means the applied education from a grandmother is to build "the future mentality of grandchildren in the future.” The step of education imposed by the three grandmothers is also very appropriate, i.e., by not spoiling grandchildren, not loving grandchildren in the wrong way, inviting grandchildren to trade in the market to train grandchildren's mental power. Furthermore, this shows the difficulty of making money. This practice is carried out to build a "great understanding" from an early age of the grandchildren that life is full of struggle, and must be lived with a strong self-mentality.

Based on the statements of the three grandchildren on the teachings and training of their grandmothers, it can be concluded that the grandchildren realize that education and care by grandmothers are the principal capital in their journey to the "maturity" of life. The grandmother, who incidentally is "a substitute for biological parents," became "central teacher" in the family. In addition to providing physical needs in the form of clothing, shelter, and food, grandmother also offers spiritual needs for the grandchildren.

In this case, grandmothers are also active in their role as "substitute teachers" who are inherent in their grandchildren. The attachment given to them is "secure attachment," not "insecure attachment." This secure attachment also makes the grandchildren "survive" in his life. The reason is there is no problem with nurturing and education between grandmothers and grandchildren. Everything works safely and comfortably for both. Different if the attachment given is insecure, it will lead to many problems in nurturing and education between grandmother and grandchildren. Thus, it will make her grandchildren unable to survive on her journey to real life.

Also, researchers make particular observations on mental resilience education in terms of unconditional education and care. The unconditional education and care contain pure values of responsibility and sincerity, that is, "really want to bring and direct their grandchildren to mature self-preparation" before facing a real life. It is this pure responsibility and sincerity that ultimately makes his grandchildren durable in life without complaining.

The grandmothers who became this research subject have the same style in educating their grandchildren's mentality, such as an authoritative style, it is the style of "enlightenment" for children, by "emotional approach" and "opening grandchildren's mindset. On the other hand, grandmothers attempt to give soulful insights and give the grandchildren an understanding. Based on the result of the research, it found that basically the education and childcare by grandmothers are types of education and childcare that are risky for children. Since they lost the figure of father 
and mother [3]. The children who are educated and raised by their grandmothers spoiled will be spoiled children in their life, have no power to face their life, easily broken and discouraged, easy to complain, mentally week, and not mentally strong [4]. The children who are educated rigorously by their grandmother "authorization" will bring the children into an atmosphere (stemming) that can make them wobbly, loose self-figure, need love, anti-social, more isolated, and other weaknesses. Three parenting styles are described by Ristia [8], namely authoritative parenting style, permissive parenting style, authorization parenting style; parenting style practiced by these three grandmothers can be categorized as authorization parenting style in which the grandmothers put forward positive logic and thought as well as not always use punishment as the final step. Between grandmothers and grandchildren, they need good communication, grandmothers also need to give control as well as balance and healthy support for grandchildren so that they grow with a healthy personality as well. In this case, grandmother's parenting style can be a mental resilience since it improves grandchildren' mentality from the sadness because they left behind and lived away from their parents. As illustrated by Utami et al. [9], they stated that the education of mental resilience is an attempt to direct the children to the pattern of the positive adaptation during or after facing the difficulties or risks. The education of mental resilience is a media of "self alteration" to the children from the situations that are full of pressure towards the circumstances that are full of opportunities in developing themselves so that they will become a better individual. Grandchildren can be categorized to have a mentally healthy with several characteristics: (1) calmly in facing the problems and pressure, (2) good self-regulation, (3) be able to manage self-emotion well, (4) self-optimism in life [12].

Generally, this finding strengthens the previous research results that were showed that grand-parenting has an essential role in forming children's mentality. Grandparents play an important role in the relationship of inter-generation and family prosperity. Grandparents can encourage emotionally, and give full of love, deliver the transmission of social-culture values, and become a primary caregiver for their grandchildren when their parents are not there [20]. Other research also found that grandparents affect positively in improving adolescent prosperity [21]. Grandparents' positive role, moreover, needs to more emphasize in family psychology [22]. Inner relationship occurs between grandmothers and grandchildren will form a personal feeling and provide meaning in grandchildren' life [23].

\section{Conclusions}

Based on the above explanation, it can be concluded that in reality, the children left by their parents to migrate. Also, children who do not get direct education from parents but by grandmothers or grandfathers or grandparents can still be successful in building a self-mentality. With the condition that the "successor caregiver" in this study is a grandmother who must have "clear concepts and actions in educating her grandchildren.” The findings of this study stated that the three grandmothers in Puring Kebumen had concepts and actions that were appropriate and clear to their grandchildren. Some other results are; grandparenting provides activities that do not spoil grandchildren except in a natural way, requiring grandchildren to solve their problems without always being assisted by their grandmother, loving grandchildren naturally. Also, introducing grandchildren early on in the real-life struggle, which in this case is trading or selling, and requiring grandchildren to live independently and complete their obligations.

\section{Acknowledgement}

The authors express the greatest gratitude to Universitas Muhammadiyah Yogyakara and Universitas Ahmad Dahlan for supporting this collaborative research.

\section{REFERENCES}

[1] D. L. Trenggonowati and Kulsum, "Analisis Faktor Optimalisasi Golden Age Anak Usia,” J. Ind. Serv., vol. 4, no. 1, pp. 48-56, 2018.

[2] A. C. Seibert and K. A. Kerns, "Attachment figures in middle childhood,” Int. J. Behav. Dev., vol. 33, no. 4, pp. 347-355, 2009.

[3] R. Fauziningtyas et al., "The experiences of grandparents raising grandchildren in Indonesia," Work. with Older People, vol. 23, no. 1, pp. 17-26, 2019.

[4] A. S. Rahmatullah, "Attachment Parenting Dalam Perspektif Psikologi Pendidikan Islam,” J. An-Nidzam Manaj. Pendidik. dan Stud. Islam, vol. 1, no. 2, 2014.

[5] M. R. A. Zakaria, "Pengalihan peran sementara pengasuhan anak dari orang tua ke nenek dan kakek Temporary role for children caring from parents to grandmother and grandfather,” Dialektika, vol. 14, no. 2, pp. 120-125, 2014.

[6] D. Sampson and K. Hertlein, "The experience of grandparents raising grandchildren. GrandFamilies: The Contemporary Journal of Research,” Pract. Policy, vol. 2, no. 1, pp. 75-92, 2015.

[7] P. Sheppard and C. Monden, "Becoming a First-Time Grandparent and Subjective Well-Being: A Fixed Effects Approach,” J. Marriage Fam., vol. 81, no. 4, pp. 10161026, 2019.

[8] R. Ristia, "Pola Asuh Grand Parenting (Studi pada 5 Keluarga di Desa Wukirsari, Imogiri, Bantul),” Universitas 
Sunan Kalijaga., 2016.

[9] C. T. Utami, "Self-Efficacy dan Resiliensi: Sebuah Tinjauan Meta-Analisis,” Bul. Psikol., vol. 25, no. 1, pp. 54-65, 2017.

[10] L. F. Rojas F., "Factors Affecting Academic Resilience in Middle School Students: A Case Study,” GiST Educ. Learn. Res. J., vol. 11, no. 11, pp. 63-78, 2015.

[11] B. C. . Dewi, G.K. \& Henu, "Resiliensi pada Remaja Yatim Piatu yang Tinggal di Panti Asuhan,” J. SPIRITS, vol. 5, no. 2, 2015 .

[12] E. Asriandari, "Resiliensi Remaja Korban Perceraian Orangtua,” J. Bimbing. dan Konseling, vol. 9, no. 4, pp. 28, 2015.

[13] A. S. Rahmatullah, "Penguatan Perilaku 'ngeloni Anak" Oleh Ibu-Ayah Sebagai Upaya Menciptakan Keluarga Harmonis Seimbang Sejak Dini,” J. Cendekia Stain Ponorogo J. Kependidikan dan Kemasyarakatan, vol. 14, no. 1, 2016.

[14] H. Hasanah, “TEKNIK-TEKNIK OBSERVASI (Sebuah Alternatif Metode Pengumpulan Data Kualitatif Ilmu-ilmu Sosial),” At-Taqaddum, vol. 8, no. 1, p. 21, 2017.

[15] S. Bhar, "Introducing Phenomenological Research Methodology in Sustainable Consumption Literature: Illustrations From India,” Int. J. Qual. Methods, vol. 18, pp. 1-14, 2019.

[16] S. M. Laverty, "Hermeneutic Phenomenology and Phenomenology: A Comparison of Historical and Methodological Considerations,” Int. J. Qual. Methods, vol.
2, no. 3, pp. 21-35, 2003.

[17] H. Ames, C. Glenton, and S. Lewin, "Purposive sampling in a qualitative evidence synthesis: A worked example from a synthesis on parental perceptions of vaccination communication,” BMC Med. Res. Methodol., vol. 19, no. 1, pp. 1-9, 2019.

[18] K. Sullivan, N.B. \& Bhattacharya, "Twenty Years of Technology Integration and Foreign Language Teaching: A Phenomenological Reflective Interview Study.,” Qual. Rep., vol. 22, no. 3, pp. 757-778., 2017.

[19] D. Elida Fuster Guillen Universidad Nacional Mayor de San Marcos, "Qualitative Research: Hermeneutical Phenomenological Method Investigación cualitativa: Método Fenomenológico Hermenéutico,” vol. 7, no. 1, pp. 201-229, 2019.

[20] M. Momeni, “No 主観的健康感を中心とした在宅高齢 者における 健康関連指標に関する共分散構造分析 Title,” vol. 21, no. 1, pp. 1-9, 2020.

[21] B. K. Ashdown and A. N. Faherty, "Parents and caregivers across cultures: Positive development from infancy through adulthood," Parents Caregivers Across Cult. Posit. Dev. from Infancy Through Adulthood, pp. 1-307, 2020.

[22] S. Attar-Schwartz, J. P. Tan, A. Buchanan, E. Flouri, and J. Griggs, "Grandparenting and Adolescent Adjustment in Two-Parent Biological, Lone-Parent, and Step-Families,” J. Fam. Psychol., vol. 23, no. 1, pp. 67-75, 2009.

[23] B. L. Neugarten and K. K. Weinstein, "The Changing American Grandparent,” J. Marriage Fam., vol. 26, no. 2, p. 199, 1964. 